\title{
Characterization of tropical viticulture in the fluminense north and northwest regions
}

\author{
Jaomara Nascimento da Silva ${ }^{1}$, Niraldo José Ponciano ${ }^{2}$, Claudio Luiz Melo Souza ${ }^{3}$, \\ Paulo Marcelo de Souza ${ }^{4}$, Leandro Hespanhol Viana ${ }^{5}$
}

\begin{abstract}
Viticulture is a recent activity in Rio de Janeiro, which has been well adapted to the edaphoclimatic conditions of the north and northwest regions of Rio de Janeiro. The aim of this study was to characterize the main socioenvironmental and technological aspects of grape production in these regions. Data were collected in 2017 and 2018, from the application of questionnaires to 16 grape producers in the regions, for descriptive statistical analysis and preparation of tables and graphs. In both regions small producers are the main investors. Most of them do not participate in associations and have technical assistance in particular. The region has favorable edaphoclimatic characteristics, mainly for the cultivation of rustic grapes, predominantly cultivar 'Niagara Rosada'. Disease control is carried out in a preventive manner, with eleven applications ranging from sprouting to days before harvest. The regions present more than one harvest per year, having supply in the season and national off season. These results may support information on the characteristics of Rio de Janeiro's viticulture, direct incentives for the activity and serve as a basis for further research, such as planning programs for grape production areas.

Index terms: Viticulture; Vitis labrusca; Rio de Janeiro.
\end{abstract}

\section{Caracterização da viticultura tropical nas regiões norte e noroeste fluminense}

Corresponding author: jaomarasilva@gmail.com

Received: September 04, 2019 Accepted: October 09, 2019

Copyright: All the contents of this journal, except where otherwise noted, is licensed under a Creative Commons Attribution License.

\section{(cc) $\mathbf{E Y}$}

\begin{abstract}
Resumo - A viticultura é uma atividade recente no Rio de Janeiro, que tem apresentado boa adaptação às condições edafoclimáticas das regiões norte e noroeste do Rio de Janeiro. O objetivo deste presente trabalho foi caracterizar os principais aspectos socioambientais e tecnológicos da produção de uvas nessas regiões. Os dados foram levantados nos anos de 2017 e 2018, a partir da aplicação de questionários aos 16 produtores de uva das regiões, e submetidas à análise estatística descritiva. Em ambas as regiões, os pequenos produtores são os principais investidores. A maior parte deles não participa de associações e tem assistência técnica de forma particular. A região apresenta características edafoclimáticas favoráveis, principalmente ao cultivo de uvas rústicas, predominantemente da cultivar 'Niagara Rosada'. O controle de doenças é realizado de forma preventiva, com onze aplicações no intervalo entre a brotação até dias antes da colheita. As regiões apresentam mais de uma colheita ao ano, tendo oferta na época da safra e da entressafra nacional. Esses resultados podem subsidiar informações sobre as características da viticultura fluminense, direcionar incentivos para a atividade e servir de base para a realização de outras pesquisas, como programas de planejamento às áreas de produção de uva.
\end{abstract}

Termos para indexação: Vitivinicultura; Vitis labrusca; Rio de Janeiro.

\footnotetext{
${ }^{1 \mathrm{P}} \mathrm{hD}$ Student in Plant Production of North Fluminense State University Darcy Ribeiro, Campos dos Goytacazes-RJ. Brazil. E-mail: jaomarasilva@gmail.com ${ }^{\text {(ORCID 0000-0002-7002-1427) }}$

${ }^{2} \mathrm{PhD}$ in Applied Economics, Professor, North Fluminense State University Darcy Ribeiro, Campos dos Goytacazes-RJ. Brazil. E-mail:

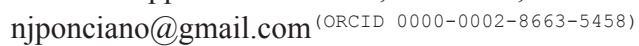

${ }^{3} \mathrm{PhD}$ in Plant Production, Professor, North Fluminense State University Darcy Ribeiro, Campos dos Goytacazes-RJ. Brazil. E-mail: claudiomelo.edu@gmail.com ${ }^{\text {(ORCID 0000-0002-0506-4121) }}$

${ }^{4} \mathrm{PhD}$ in Applied Economics, Professor, North Fluminense State University Darcy Ribeiro, Campos dos Goytacazes-RJ. Brazil. E-mail: pmsouza@uenf.br(ORCID 0000-0002-5788-915X)

${ }^{5} \mathrm{PhD}$ in Plant Production of North Fluminense State University Darcy Ribeiro, Campos dos Goytacazes-RJ. Brazil. E-mail: lehespanhol@yahoo.com ${ }^{\text {(ORCID 0000-0003-4187-1710) }}$
} 


\section{Introduction}

The expansion of viticulture is an important activity for the sustainability of family farming in the various regions of Brazil. According to data from the Brazilian Institute of Geography and Statistics (Instituto Brasileiro de Geografia e Estatística - IBGE, 2018), more than 50\% of the total area $(75,744 \mathrm{ha})$ is concentrated in the state of Rio Grande do Sul (48,397 ha), followed by Pernambuco (8,537 ha) São Paulo (7,348 ha), Santa Catarina (4,426 ha) and Paraná (3,664 ha), and although in smaller area, but also growing in Espirito Santo, Mato Grosso, Goiás, Ceará and Rio de Janeiro.

Viticulture can be divided into three categories: temperate, subtropical and tropical, according to Camargo et al. (2011). The regions of 'Vale do Submédio São Francisco', Northwest Paulista and Northern Minas Gerais are the main production centers of regions with characteristics of tropical climate.

Tropical viticulture can be found in the Fluminense North and Northwest Regions, since this category is typical of regions where winter is not severe and does not naturally induce vine dormancy, as in the regions of the present research. In these regions, due to the lack of cold, the 'Niagara Rosada' grapevine does not go into dormancy, but only undergoes a vegetative rest. Thus, immediately after pruning, the application of budding inducers is necessary to stimulate and standardize budding (VIANA et al., 2008).

Among the cultivars such as 'Niágara Rosada', 'Isabel' and 'Niágara Branca', which account for more than $50 \%$ of the marketed volume of fresh grapes in the national market (CAMARGO; MAIA, 2008), can be found all three in the north and northwest region of Rio de Janeiro, with 'Niagara Rosada', the predominant cultivar. These rustic varieties have better adaptation to the edaphoclimatic conditions of the regions, reaching Total Soluble Solids values around $15^{\circ}$ Brix, within the value considered good for the harvest point, among the national and international fruit marketing standards, as presented by Antoniolli. (2005).

According to Murakami, (2002) and Viana et al. (2006), the high light and high average temperatures throughout the year in the regions favor the growth and production of photoassimilates, allowing the occurrence of two production cycles per year.

With regard to grape production in these areas, viticulture has been implemented due to favorable soil and climate conditions for production in the last ten years, and spread by Silva et al. (2008), Pommer et al. (2009), Almeida et al. (2017), among other researchers, who has been studying about the ecophysiology and phenology of the vine in the north of the state to know the best physiological behavior of plants in this region.
It should be emphasized that although these ariables are relevant points in studies on grape production, the socioeconomic and management characteristics should be considered equally important, especially when there is a shortage of studies to this subject. According to Vilaboa and Diaz (2009), Borja-Bravo et al. (2016) the characterization of producers and production systems is crucial for the development of policies, since it allows to know the formation of production systems, their technological components, the potential and limitations in relation to other systems.

It is known that the activity shows great importance in the generation of jobs and income, providing economic conditions for the maintenance of families in small properties throughout the country, according to studies by Zarth et al. (2011) in southwestern Paraná, by Anzanello et al. (2012) in Rio Grande do Sul and by Costa et al. (2012) in the Jales Region, SP.

In this context, the main objective of this study was to characterize the profile of the viticulturist and the phytotechnical management of grape in the Fluminense North and Northwest Region, as a source of information for the register of the fluminense viticulture. Thus, to understand the process of insertion of viticulture, some aspects were identified that make it possible to create a minimal identity of the grape production areas in the State of Rio de Janeiro.

\section{Material and methods}

The focus areas of this study are the developing municipalities with the wine sector, such as: Cardoso Moreira, Campos dos Goytacazes, Carapebus, São Fidélis in the North Fluminense, and Bom Jesus do Itabapoana, Varre Sai, Cambuci, São José de Ubá and Italva in the Northwest Fluminense (Figure 1).

For data collection, information was sought from state and municipal authorities and farmers' associations to know the total number of winemakers in the regions. The survey was conducted between April 2017 and May 2018 through questionnaires applied directly to the 16 winemakers in the regions, which is equivalent to the total number of winemakers (Table 1). To evaluate and compare production systems used by the producers who were part of the research, the following information was raised: 


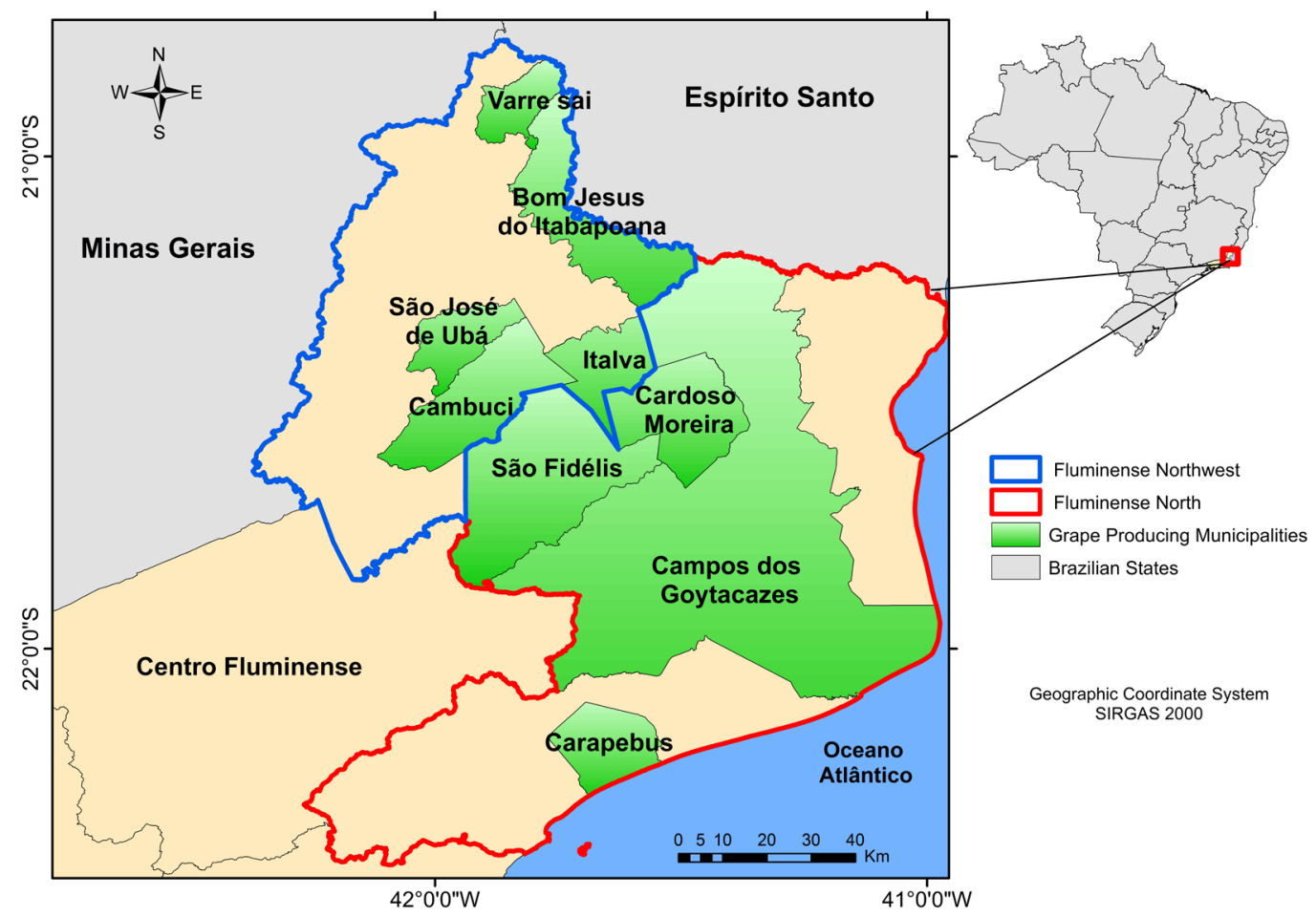

Figure 1. Characterization of grape production areas in the Fluminense North and Northwest Regions.

Table 1. Producers interviewed in the survey.

\begin{tabular}{cccc}
\hline (North Region) & Number of Producers & (Northwest Region) & Number of Producers \\
\hline Campos dos Goytacazes & 1 & Bom Jesus do Itabapoana & 1 \\
Cardoso Moreira & 1 & Cambuci & 2 \\
Carapebus & 1 & Italva & 1 \\
São Fidelis & 2 & São José de Ubá & 4 \\
& & Varre Sai & 3 \\
Total & $\mathbf{5}$ & & $\mathbf{1 1}$ \\
\hline
\end{tabular}

Source: Prepared by the authors

1-Socioeconomic status: gender, age group, education, time spent in grape production, forms of collective organization, technical assistance, source of financial resources, labor used;

2-technologies: cultivars used, rootstocks, crop planting year, vine age, irrigation, fertilization, phytosanitary management, number and timing of product applications, use of Personal Protective Equipment (PPE), weed management, pruning seasons, fruiting and harvesting.

After the interviews, the observed data were tabulated and submitted to descriptive statistics.

\section{Results and discussion}

\section{Winegrower Profile}

Among the 16 grape producers, $68.75 \%$ are male and $31.25 \%$ are female. During the research, it was observed that $44 \%$ are aged between 29 to 38 years old, which shows that viticulture is being developed mostly by workers who are in full activity, as observed by Costa et al. (2012). As for education, 50\% have higher education, $25 \%$ high school and 25\% elementary school (Table 2). These variables are factors that directly influence the availability of new technology adoption, corroborating with Velasco et al., (2009) and Velez, (2012). 
Table 2. Profile of the winegrowers in the Fluminense North and Northwest Regions.

\begin{tabular}{llllll}
\hline Gender & n (\%) & Age (years) & n (\%) & Education & n (\%) \\
\hline Female & $5(31.25)$ & $18-28$ & $1(6.25)$ & Illiterate & $0(0.0)$ \\
Male & $11(67.75)$ & $29-38$ & $7(44.0)$ & Elementary School & $4(25.0)$ \\
& & $39-48$ & $2(12.5)$ & High school & $4(25.0)$ \\
& & $29-58$ & $(12.5)$ & University Education & $8(50.0)$ \\
\hline
\end{tabular}

Source: Prepared by the authors

Producers indicated that they had an average of 15 years of experience in grape production, of which $50 \%$ were in the range of 1 to 5 years, $25 \%$ of 6 to 10 years; and $25 \%$ between 11 and 15 years. This can also reflect on economic development, and to continue the generations with this activity and the expansion of new areas by other producers.

The evaluation of the available workforce employed is very important to understand three points: the type of occupation, the working time and the origin of the workforce (PERONDI, 2007). In $75 \%$ of the surveyed properties, there were between 2 and 4 workers per hectare, and among these, there is hiring of external workers, even temporary, to perform the pruning and harvesting of grapes. Because it is a new culture, it is difficult to find specialized labor for the required management, which for some producers, this lack is one of the main obstacles of viticulture. However, it is observed that the cultivation allowed the employment of workers for almost the whole year, contributing to the presence of man in the countryside and reduction of rural exodus.

In addition to labor, another major limitation to winegrowers in the regions is related to the producers' organization. It was noted that $43.75 \%$ participate in associations, but there are no associations directly linked to viticulture, as observed by Costa et al. (2012) in the Northwest Paulista. And unlike the more traditional regions, such as Rio Grande do Sul and Paraná, as described by Anzanello et al. (2012) and Zarth et al. (2011), respectively. It can be inferred that agricultural associations and cooperatives would allow for better marketing planning, so that all producers obtain greater and better satisfactory economic returns.

Agricultural policies can be arrangements of instruments that stimulate agricultural production. In this context, the 'Fruiting Program' is an agricultural policy that developed grape cultivation in the regions, as it encouraged and subsidized $62.5 \%$ of winemakers, after some producers invested on their own. Costa et al. (2012) observed that most winemakers also invested in grapes in Jales (SP), through an agricultural program, the National Program for Strengthening Family Farming (Programa Nacional de Fortalecimento da Agricultura Familiar PRONAF). This shows that several agricultural promotion programs have been driving this activity in several regions.
Given the difficulties, the presence of technical assistance was questioned, and it was noted that $88 \%$ receive assistance, mostly, privately or in agreement with the Brazilian Micro and Small Business Support Service (Serviço Brasileiro de Apoio às Micro e Pequenas Empresa - Sebrae). The producers reported that the technical assistance established by the Fruiting Program was suspended, and had to enter into an agreement, so as not to lose the agricultural technician who guided them in the formation of the vineyards. Thus, only one technician makes monthly visits to all properties, and this lack of technical assistance can influence the management practices performed by producers, besides demonstrating the needs of more professionals specialized in viticulture.

On the other hand, only $40 \%$ of the winegrowers attended field days and management and marketing information courses. Fourteen winegrowers (90\%) were interested in participating in more courses aimed at viticulture, in order to improve information on phytotechnical issues and production flow. It is emphasized at this point, the need for guidance on economic factors of production and economic viability, as these are as important as the phytotechnical issue, since through them, all links in the production chain can be strengthened.

\section{Phytotechnical characterization of Rio de Janeiro's viticulture}

Crop management should be based on results obtained in the region where the vine is intended to be cultivated, as the climate and soil conditions are not always the same. It was observed that all producers perform soil analysis and fertilization according to local technical recommendation.

Maintenance fertilization of the vineyards is predominantly performed after pruning, with organic fertilization (poultry litter and cattle manure) and mineral fertilization (nitrogen, potassium and phosphate), the latter being in smallest amount in comparison with potassium and nitrogen fertilization. Fertigation is a technology used by some producers participating in the research. The use of this technology can be a way to increase the efficiency of fertilization and irrigation system, as well as saving labor, as reported by Pires et al. (2011). 
Wine production is an activity very much influenced by the weather, which is important in defining the potentialities of the regions (BACHK et al., 2013). In the last three years, $37.5 \%$ of the producers had problems with lack of water, due to less rainfall, and consequently lower production in both harvests throughout the year. Thus, drip irrigation already carried out by producers is a technology that has allowed optimizing the use of water. On the other hand, it is also necessary to pay attention to the rainy period for many days, especially from the beginning of ripening to harvest, as it is a predisposing factor to the main fungal diseases.
In the distribution of cultivated varieties there are nine varieties, among which stands out the cultivation of 'Niagara Rosada' (Figure 2). Besides the in natura consumption, the processing of these cultivars for juice and wine production can be a strategic source of commercialization of the wine sector, mainly for Rio de Janeiro Northwest region, where there has been shown greater potential for supply and demand of these byproducts, such as in the municipalities of 'Varre Sai' and 'Bom Jesus do Itabapoana'.

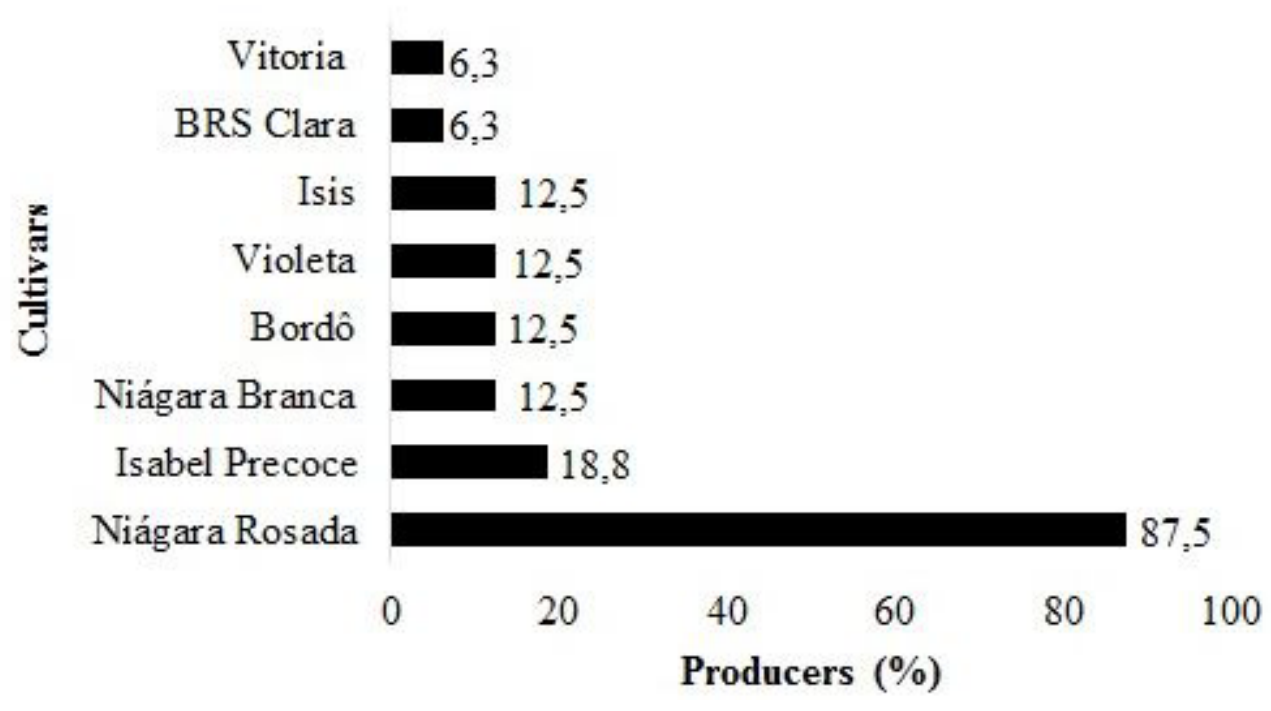

Figure 2. Distribution of grape varieties grown in the surveyed properties.

The seedlings of the varieties are grafted on the 'IAC-572 Jales' or 'IAC 766' rootstocks. According to Tecchio et al. (2007) and Silva et al. (2010) they are widely used because of the compatibility with the crown varieties and adaptability in various soils, and as for the greater choice by 'Niagara Rosada', it can be attributed to rusticity and consequently better adaptation to the regions.

The predominant conduction system in the vineyards is the trellis system, as in southwestern Paraná, according to Zarth et al., (2011). This system allows an extensive vegetative canopy area, which can develop high number of bunches and high productivity, and due to its productivity, favors the economic profitability. Of the sixteen production areas, fourteen are protected by shade screen, and although the investment for the screen is considered relatively high, the use of the screen can control the attack of birds and bats, as well as providing a favorable microclimate for fruit development.

The use of pesticides (herbicides, insecticides, fungicides) is frequent during most of the production period. In weed management, it was observed that $63.5 \%$ apply herbicides, and in phytosanitary management of pests and diseases, $68.75 \%$ work with a preventive calendar that begins after sprouting. In general, applications occur every eight to ten days, with eleven applications in the interval from sprouting to days before harvest. During the application, $68.75 \%$ wear only the PPE boot and cap, and $82.5 \%$ claimed that the PPE slightly disrupts the service. It can also be pointed out that producers during almost the entire growing season are at risk of poisoning, requiring guidance on pesticide management.

About nine commercial products are used, all of which have a recommendation for the crop, $55.5 \%$ of the products have systemic action, and $63 \%$ of the products are classified as very dangerous to the environment, according to the Environmental Hazard Potential Classification (Table 3). In addition to these products, alternative products are used, although producers still do not see the same efficiency found by pesticides, they have gradually inserted some, with the concern of having a more sustainable product. 
Table 3 - Products used in phytosanitary management of grape pests and diseases in the Fluminense North and Northwest Regions.

\begin{tabular}{cccccc}
\hline Commercial Name & Active ingredient & Chemical group & HT & ET & IS \\
\hline Amistar & Azoxystrobin & Strobilurins & IV & II & 7 \\
Cabrio Top & Pyraclostrobin & Alkylenobis & III & II & 30 \\
Cercobin & Methyl thiophanate & Benzimidazole & I & II & 14 \\
Cerconil & Chlorotalonil & Benzimidazole & I & II & 14 \\
Cuprogarb & Copper oxychloride & Inorganic & IV & III & 1 \\
Cuzarte & Mancozeb, Cimoxanil & Acetamide & III & III & 7 \\
Folicur & Tebuconazole & Triazole & III & II & 14 \\
Orthocide & Mancozeb & Dicarboximide & I & II & 1 \\
Ridomil Gold & Metalaxyl-M & Alkylenobis & I & II & 7 \\
\hline
\end{tabular}

HT- Human toxicity: I- Extremely toxic, II- Highly toxic, III- Fairly Toxic, IV- Little toxic; TA- Environmental Toxicity: I- Highly dangerous, II- Very dangerous, III- Fairly Dangerous, IV- Little Dangerous; IS- Confidence Interval.

Source: Prepared by the authors

The main diseases that attack the vineyards surveyed, according to information from winegrowers are: mildew (Plasmopara viticola), rot (Colletotrichum gloeosporioides), anthracnose (Elsinoe ampelina), rust (Phakospora euvitis). As for the main pests they reported the attack of white mealybug (Pseudococcus sp), beetles and birds at the time of fruiting. However, according to producers, the implementation of the preventive calendar has been very effective in phytosanitary management.

Of the interviewed producers, $81.25 \%$ perform short pruning in July, September and November and long pruning in January, February and April, and the harvesting season occurs largely between 110 and 120 days after pruning. It is worth noting that $12.75 \%$ that perform less pruning, due to the location of production (municipality of Varre Sai) have more days with lower temperatures than other areas.

According to Hespanhol-Viana (2009) there is a period of 103 days for the vine to complete its cultivation in months with higher temperatures, and 123 days in pruning done at lower temperatures in the northern region of Rio de Janeiro. This demonstrates the interaction between meteorological factors with other components of the production system, influencing grape production throughout the year. It is interesting, therefore, to know the phenological phases of the vine, as these can be influenced by air temperature, rainfall and hours of insolation, to increase the harvest period and good productivity (JUBILEU et al., 2010).

For the fruiting period, $93.75 \%$ of the producers apply Ethrel ${ }^{\circledR} 720$ between 15 and 20 days before fruiting pruning. The product when applied at certain stages of plant development causes changes in its physiological and biochemical processes, such as promoting defoliation, according to the objective intended by the producers.

Because both regions present characteristic of tropical climate, where there are no minimum temperatures to induce dormancy, the hydrogenated cyanamide, a type of sprout inducer, is applied to stimulate and standardize sprouting, according to Hespanhol-Viana (2009). With the use of this inductor in conjunction with favorable conditions, as observed in most municipalities, there is the possibility of two or more harvests per year, and avoiding uneven and insufficient shoots after pruning. Thus, we highlight a factor that, integrated with others presented in this topic, provides more than one harvest throughout the year in both regions (Table 4).

Table 4- Timetable of pruning and harvesting in the Fluminense North and Northwest Region.

\begin{tabular}{l|l|l|l|l|l|l|l|l|l|l|l|l}
\hline & Jan & Feb & Mar & Apr & May & Jun & Jul & Aug & Sept & Oct & Nov & Dec \\
\hline Short Pruning & & & & & & & $\mathrm{x}$ & & $\mathrm{x}$ & & $\mathrm{x}$ & \\
\hline Long pruning & $\mathrm{x}$ & $\mathrm{x}$ & & $\mathrm{x}$ & & & & & & & & \\
\hline Early Harvest & & & & & $\mathrm{x}$ & $\mathrm{x}$ & $\mathrm{x}$ & & & & & \\
\hline Main Harvest & $\mathrm{x}$ & $\mathrm{x}$ & & & & & & & & & $\mathrm{x}$ & $\mathrm{x}$ \\
\hline
\end{tabular}

Source: Prepared by the authors 


\section{Conclusions}

The viticulturist profile tends to remain as an income generating activity, responsible for the absorption of the labor force and, therefore, may continue in regions, supported by incentives for production and commercialization.

Both regions present viticulture as a source of family farming diversification and sustainable development. There are nine varieties grown between the regions, both for fresh consumption, as well as processing juices, wines and sweets, especially the 'Niagara Rosada' harvested almost all year round.

There is a lack of specialized assistance to meet the demands of growers during management, and neglect in the use of PPE by most wine growers. The scarcity of rainfall at certain times was pointed out as the main problem in the conduction of the vineyards.

This information can direct incentives for the sector and establish market strategies, not only as a component of the production unit, but also as a parameter for the expansion of tropical viticulture.

The results may support other research, based on the knowledge of the wine growers profile and the technological parameters, in order to provide the producer with the optimization of factors involved in management, considering the sustainable rural development of the regions.

\section{References}

ALMEIDA, L.V.B.; FIGUEIREDO, F.A.M.M.A.; DE DEUS, B.C.; VIANA, L.H.; FERRAZ, T.M.; MARTINS, A.O.; SMITH, R.E.B.; CAMPOSTRINI, E. Plastic covering film can reduce midday depression photosynthesis of field-grown tropical grapevine in high photosynthetic photon flux. Acta Horticulturae, The Hague, v.1, p.255-262, 2017.

ANTONIOLLI, L.R. Sistema de produção de uva de mesa do norte de Minas Gerais: colheita e manuseio pós-colheita. Bento Gonçalves: Embrapa Uva e Vinho, 2005. (Sistema de Produção, 11). Disponível em https:// sistemasdeproducao.cnptia.embrapa.br/FontesHTML/ Uva/MesaNorteMinas/colheita.htm. Acesso em: 03 set. 2019.

ANZANELLO, R. Caracterização da viticultura no Rio Grande do Sul por meio da análise dos dados do Cadastro Vitícola. Pesquisa Agropecuária Gaúcha, Porto Alegre. v.18, n.1, p 67-73, 2012.
BACHK, Á.J.; BRUNA, E.D.; DALBÓ, M.A. Mudanças climáticas e a produção de uva no vale do Rio do PeixeSC. Revista Brasileira de Fruticultura, Jaboticabal, v.35, n.1, p.159- 169, 2013.

BORJA-BRAVO, M.; REYES-MURO, L.; GARCIASALAZAR, J. A.; ALMERAYA-QUINTERO, S. X. Tipologia dos produtores de uva (Vitis vinifera L.) em Aguascalientes, México. Revista Mexicana Ciencia Agrícola, Texcoco, v.7, n.2, p.249-261, 2016.

CAMARGO, U. A.; MAIA, J. D. G. Cultivares de uvas rústicas para regiões tropicais e subtropicais. In: BOLIANI, A.C.; FRACARO, A.A.; CORREA, L.F. Uvas rústicas de mesa: cultivo e processamento em regiões tropicais. Piracicaba: Agroceres, 2008. p.63.

CAMARGO, U. A.; TONIETTO, J.; HOFFMANN, A. Progressos na viticultura brasileira. Revista Brasileira de Fruticultura, Jaboticabal, v. 33, p.144- 149, 2011. Número especial.

COSTA, T.V. da; TARSITANO, M.A.A.; CONCEIÇÃO, M.A.F. Caracterização social e tecnológica da produção de uvas para mesa em pequenas propriedades rurais da região de Jales-SP. Revista Brasileira de Fruticultura, Jaboticabal, v.34, n.3, p.766-773, 2012.

HESPANHOL-VIANA, L. Fenologia e quebra de dormência da videira 'Niagara Rosada' cultivada na região Norte Fluminense e diferentes épocas de poda. 2009. Tese (Doutorado em Produção Vegetal) - Universidade Estadual do Norte Fluminense Darcy Ribeiro, Campos dos Goytacazes, 2009.

IBGE. Instituto Brasileiro de Geografia e Estatística. SIDRA - banco de dados. Disponível em: http://www. sidra.ibge.gov.br/bda/tabela/listabl.asp? $\mathrm{z}=\mathrm{t} \& \mathrm{c}=1613$. Acesso em: 20 set. 2018.

JUBILEU, B.S.; SATO, A.J.; ROBERTO, S.R. Caracterização fenológica e produtiva das videiras 'Cabernet Sauvignon' e 'Alicante' (Vitis vinifera L.) produzidas fora de época, no norte do Paraná. Revista Brasileira de Fruticultura, Jaboticabal, v.32, n.2, p.451462, 2010.

MURAKAMI, K.R.N. Caracterização fenológica da videira cv. Itália (Vitis vinifera $L$.) sob diferentes épocas de poda na região Norte do estado do Rio de Janeiro. 2002. Tese (Mestrado em Produção Vegetal) - Universidade Estadual do Norte Fluminense Darcy Ribeiro, Campos dos Goytacazes, 2002. 
PERONDI, M.Â. Diversificação dos meio de vida e mercantilização da agricultura familiar. 2007. Tese (Doutorado) - Universidade Federal do Rio Grande do Sul, Porto Alegre, 2007.

PIRES, R.C.M.; FURLANI, P.R.; RIBEIRO, R.V.; JÚNIOR, D.B.; SAKAI, E.; LOURENÇÃO, A. L.; NETO, A.T. Irrigation frequency and substrate volume effects in the growth and yield of tomato plants under greenhouse conditions. Scientia Agricola, Piracicaba, v. 68, n. 4, 2011.

POMMER, C.V; MENDES, L.S; HESPANHOL-VIANA, L. BRESSAN-SMITH, R. Potencial climático para a produção de uvas em Campos dos Goytacazes, Região Norte Fluminense. Revista Brasileira de Fruticultura, Jaboticabal, v.31, n.4, p.1076-1083. 2009.

SILVA, F.C.C.D.U.; VIANA, A.P.U.; SILVA, M.G.O.D.U.; OLIVEIRA, J.G.D.U.; GOMES FILHO, A.U. Caracterização química e determinação dos estádios fenológicos de variedades de videiras cultivadas no Norte Fluminense. Revista Brasileira de Fruticultura, Jaboticabal, v.30, n.1, p.38-42, 2008.

SILVA, T.P.; PIO, R.; BUSCH SALIBE, A.; DALASTRA, I.; STANGARLIN, J.R.; KUHN, O.J. Avaliação de portaenxertos de videira em condições subtropicais. Bragantia, Campinas, v. 69, n. 1, p.93-97, 2010.

TECCHIO, M. A.; MOURA, M. F.; HERNANDES, J. L.; PIO, R.; WYLER, P. Avaliação do enraizamento, desenvolvimento de raízes e parte aérea de portaenxertos de videira em condições de campo. Ciência e Agrotecnologia, Lavras, v.31, p.1857-1861, 2007.
Velasco, F. J.; Ortega, S. L.; Sánchez, C. E. y Urdaneta, F. Factores que influyen sobre el nivel tecnológico presente en las fincas ganaderas de doble propósito localizadas en el estado de Zulia, Venezuela. Revista Científica. 19(2):187-195, 2009.

Vélez, I. A. Factores que influyen en la probabilidad de adopción tecnológica en unidades de producción familiar en Guanajuato, México. Tesis Doctoral. Colegio de Postgraduados, 2012.

VIANA, L.H.; GUIMARÃES, J. C.; POMMER, C. V.; BRESSAN-SMITH, R. Fenologia da videira 'Niagara Rosada' (Vitis sp.) sob duas épocas de poda na região norte do Estado do Rio de Janeiro. In: CONGRESSO BRASILEIRO DE FRUTICULTURA, 20., 2008, Vitória. Anais [...]. CD-ROM

VIANA, L.H.; MORENO, D.M.V.; GUIMARÃES, J.C.; RIBEIRO, L.S.; BOTTINI, R.; BRESSAN-SMITH, R. Estudos sobre o efeito de GA3 em uva de mesa "Itália", produzidas na região Norte Fluminense. In: CONGRESSO BRASILEIRO DE FRUTICULTURA, 19., 2006, Cabo Frio. Anais [...] v.1, p.1-1.

VILABOA, A. J.; DÍAZ, R. P. Caracterización socioeconómica y tecnológica de los sistemas ganaderos en siete municipios del estado de Veracruz, México. Zootecnia Tropical, Macaray, v.27, n.4, p.427-439, 2009.

ZARTH, N. A; CITADIN, I; PERONDI, M.A; DONAZZOLO, J. Perfil sócio-econômico da vitivinicultura na Região Sudoeste do Paraná. Synergismus scyentifica UTFPR, Pato Branco, v. 6, n.1, p.1-10, 2011. 